Prepared for the U.S. Department of Energy

under Contract DE-AC05-76RL01830

\title{
Area C Borrow Site Habitat Assessment
}

\author{
MR Sackschewsky \\ JL Downs
}

December 2009

\section{Pacific Northwest}

NATIONAL LABORATORY

Proudly Operated by Battelle Since 1965 


\title{
DISCLAIMER
}

This report was prepared as an account of work sponsored by an agency of the United States Government. Neither the United States Government nor any agency thereof, nor Battelle Memorial Institute, nor any of their employees, makes any warranty, express or implied, or assumes any legal liability or responsibility for the accuracy, completeness, or usefulness of any information, apparatus, product, or process disclosed, or represents that its use would not infringe privately owned rights. Reference herein to any specific commercial product, process, or service by trade name, trademark, manufacturer, or otherwise does not necessarily constitute or imply its endorsement, recommendation, or favoring by the United States Government or any agency thereof, or Battelle Memorial Institute. The views and opinions of authors expressed herein do not necessarily state or reflect those of the United States Government or any agency thereof.

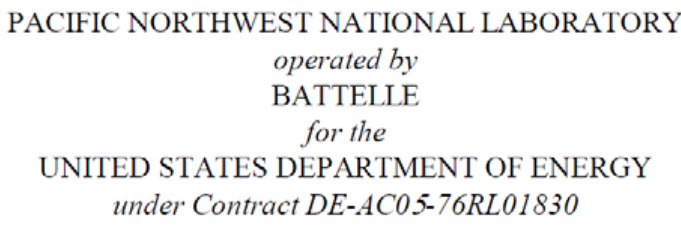

Printed in the United States of America

Available to DOE and DOE contractors from the Office of Scientific and Technical Information,

P.O. Box 62, Oak Ridge, TN 37831-0062;

ph: (865) 576-8401

fax: (865) $576-5728$

email: reports@adonis.osti.gov

\author{
Available to the public from the National Technical Information Service, \\ U.S. Department of Commerce, 5285 Port Royal Rd., Springfield, VA 22161 \\ ph: (800) 553-6847 \\ fax: $(703) 605-6900$ \\ email: orders@ntis.fedworld.gov \\ online ordering: http://www.ntis.gov/ordering.htm
}

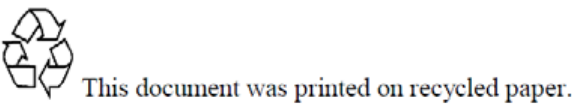




\section{Area C Borrow Site Habitat Assessment}

MR Sackschewsky

JL Downs

December 2009

Prepared for

CH2M HILL Plateau Remediation Company and the U.S. Department of Energy under Contract DE-AC05-76RL01830

Pacific Northwest National Laboratory

Richland, Washington 99352 


\section{Summary}

Pacific Northwest National Laboratory (PNNL) staff conducted a field survey of vegetation on the proposed Area C Borrow Source for the Hanford Site during 2009 to assess the current status and quality of habitats in selected portions of the area. PNNL completed this assessment to assist the U.S. Department of Energy (DOE) and CH2M HILL Plateau Remediation Company address requirements of an April 2009 memorandum of understanding with the Washington State Historic Preservation Office and the Advisory Council on Historic Preservation. Results of the PNNL assessment indicate that the area previously identified as a bitterbrush/Indian ricegrass stabilized dune element occurrence by the Washington State Natural Heritage Program is better described as a sagebrush/needle-and-thread grass element occurrence of fair to good quality. An additional new habitat polygon is described adjacent to this element occurrence, which is also sagebrush/needle-and-thread grass but of poor quality. The 145acre area proposed for initial borrow site development was found to be a very low-quality plant community dominated by cheatgrass. 


\section{Abbreviations}

ACHP

DOE

MOA

PNNL

SHPO

SR 240

WNHP

Advisory Council on Historic Preservation

U.S. Department of Energy

Memorandum of Agreement

Pacific Northwest National Laboratory

State Historic Preservation Office

State Route 240

Washington Natural Heritage Program 


\section{Contents}

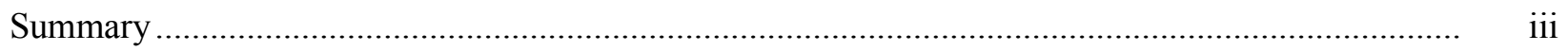

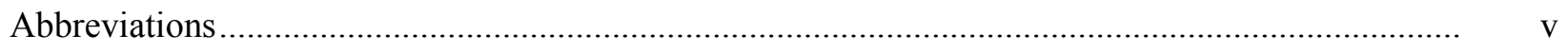

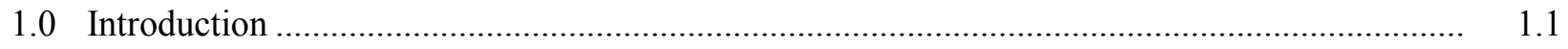

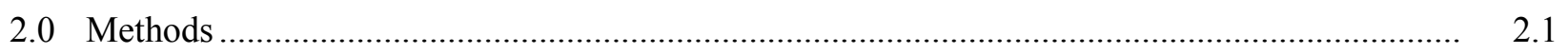

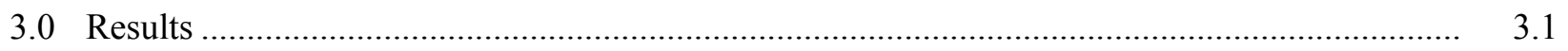

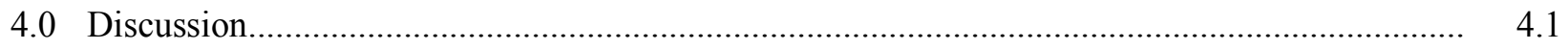

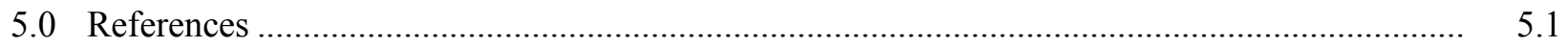

\section{Figures}

1.1. Location of the Area C Borrow Site on the Hanford Site ...................................................... 1.2

1.2. Vegetation Cover Types Within and Around Area C ........................................................... 1.4

2.1. Sample Site Locations for the Dune and Borrow Site Study Areas......................................... 2.2

2.2. Diagram Showing Layout of Quadrats and Area Sampled at Each Sampling Site .................... 2.3

4.1. Proposed Revised Plant Community Designations for the Dune Portion of Area C .................. 4.2

4.2. Area C Needle-and-Thread Grass Community ........................................................................ 4.4

4.3. Area C Needle-and-Thread Grass Community .................................................................... 4.4

4.4. Area C Needle-and-Thread Grass Community, Portion with High Sandberg's Bluegrass Cover.

4.5. Dune Area at Sample Point 3, Looking Northwest Toward Access Road, Showing Greater Cheatgrass Cover, Less Needle-and-Thread Grass Cover.....

4.6. Cheatgrass-Dominated Community Within Proposed Initial Borrow Area, near Southern Border, Looking Northwest

4.7. Cheatgrass-Dominated Community Within Proposed Initial Borrow Area, near Southern Border, Looking East.

4.8. Old Road near the Northeastern Corner of the Proposed Initial Borrow Area, Looking West ....

\section{Tables}

3.1. Species Richness at the Dune and Borrow Area Sites ....................................................... 3.1

3.2. Average Total and Relative Canopy Cover at the Dune and Borrow Sites ................................ 3.1

3.3. Canopy Cover Percentages and Percent Frequency by Sample Location and Species for the Dune Portion of Area C

3.4. Canopy Cover Percentages and Percent Frequency by Sample Location and Species Code Within the Initial Borrow Site Area.

3.5. Species Observed Within Sample Plots at the Dune and Borrow Sites Within Area C 


\subsection{Introduction}

The U.S. Department of Energy (DOE) has been working for several years to develop a borrow source to provide fine-textured soil materials that would be suitable for use in protective barriers to support remediation of waste sites on the Hanford Site. An approximately 2,300-acre site, referred to as Area C, has been identified as the preferred source for these materials. The site is located due south of the 200 West Area and State Route 240 (SR 240), near the Rattlesnake barricade (Figure 1.1).

A need for up to 30,000 cubic yards of fine-grained material was initially identified. Procurement of this quantity of material would disturb approximately 8 acres to a depth of 6 to 10 feet. An additional 3 acres likely would be disturbed to support the excavation work; thus, approximately 11 acres would be required for the initial borrow work. Additional borrow activities would be possible in the future.

The DOE characterized an approximate 145-acre portion of Area C for suitability as a source of finegrained soil and determined that the entire area would be suitable. The initial 11-acre development is proposed to occur somewhere within the 145-acre characterized area.

During the planning process, it became apparent that the proposed borrow site development would affect portions of a traditional cultural property known as Laliik (essentially Rattlesnake Mountain), which is of religious and cultural significance to area tribes. Potential adverse effects include impacts on the viewshed, noise level, and air quality, as well as the loss of native vegetation and wildlife habitat.

To address these impacts, DOE entered into a Memorandum of Agreement (MOA) with the Washington State Historic Preservation Office (SHPO) and the Advisory Council on Historic Preservation (ACHP). ${ }^{1}$ The MOA, which became effective in April 2009, contains a number of stipulations that DOE has agreed to carry out, including stipulation A.I.2 - "In consultation with the SHPO, ACHP, and Tribes, DOE will update the habitat quality determination for the Area $\mathrm{C}$ borrow source, specifically focusing on the stabilized dune areas...."

To address this specific MOA stipulation, Pacific Northwest National Laboratory (PNNL) conducted a field survey of the areas in question. This report provides a summary of the methods, results, and interpretation of that survey.

The irregularly shaped Area C is located south of SR 240 and extends from Gate 117 and Benson Ranch on the west to Gate 115 on the east. There are several distinct topographic areas and habitat types within the site, including a wide bottomland area along Cold Creek (the western portions of which were farmed prior to the creation of the Hanford Site, while the rest likely were grazed), sandy uplands between Cold Creek and SR 240, near-surface basalt formations near the western end, and the lower portions of Rattlesnake Mountain to the south and west.

\footnotetext{
${ }^{1}$ Advisory Council on Historic Preservation. 2009. Letter to David Brockman (U.S. Department of Energy, Richland Operations Office), "Memorandum of Agreement for Use of Borrow Source at Area C, Hanford Site," April 6, 2009. Letter and Enclosure 1, the Memorandum of Agreement, on file at the DOE Richland Operations Office, Richland, Washington.
} 


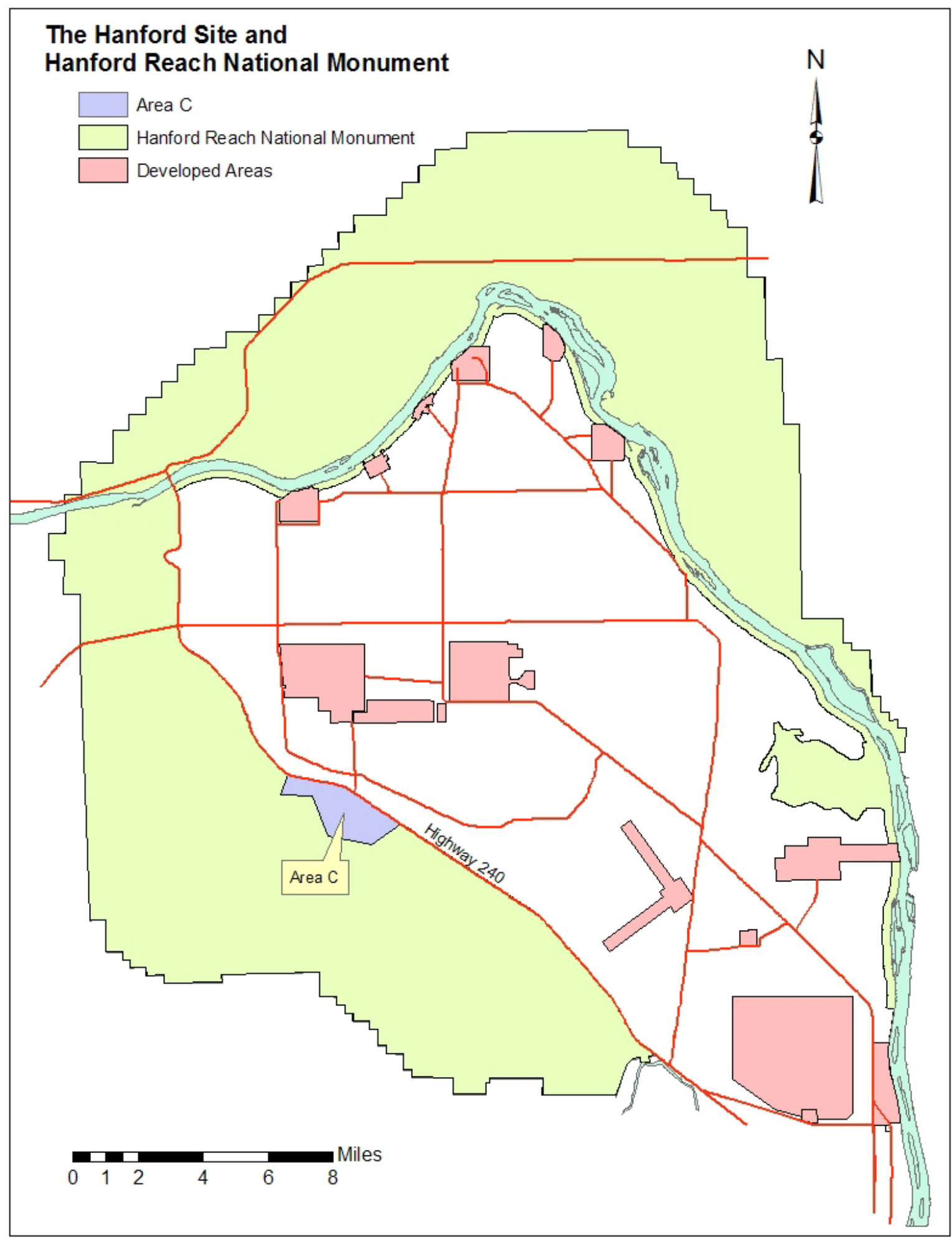

Figure 1.1. Location of the Area C Borrow Site on the Hanford Site 
Previous survey and mapping efforts delineated several different plant community types within Area C (Figure 1.2). Most of the area was mapped as Sandberg's bluegrass (Poa secunda)/cheatgrass (Bromus tectorum) by The Nature Conservancy of Washington in the mid-1990s (Pabst 1995). Smaller portions were mapped as big sagebrush (Artemisia tridentata)/bluebunch wheatgrass (Pseudoroegneria spicata), big sagebrush/needle-and-thread grass (Hesperostipa comata), and bitterbrush (Purshia tridentata)/Indian ricegrass (Achnatherum hymenoides) community types. Subsequent mapping by PNNL characterized the abandoned agricultural fields and rabbitbrush (Ericameria nauseosa)/bunchgrass mosaic community types (PNNL 2008).

All of Area C burned during the 24 Command fire in 2000, and lands to the west of the Area C access road burned again in the Wautoma fire in 2007.

Although it is not within the area proposed for initial development, the sandy, stabilized dune area between SR 240 and the 145-acre borrow area is of particular interest to the tribes. This area was designated as a bitterbrush/Indian ricegrass element occurrence by The Nature Conservancy and Washington Natural Heritage Program in the mid-1990s. A plant community element occurrence is a community that is representative of a native plant community type with relatively little disturbance and a relatively low amount of exotic species. Therefore, we examined both the dune area and the proposed 145-acre borrow area to fulfill stipulation A.I.2 of the MOA. 


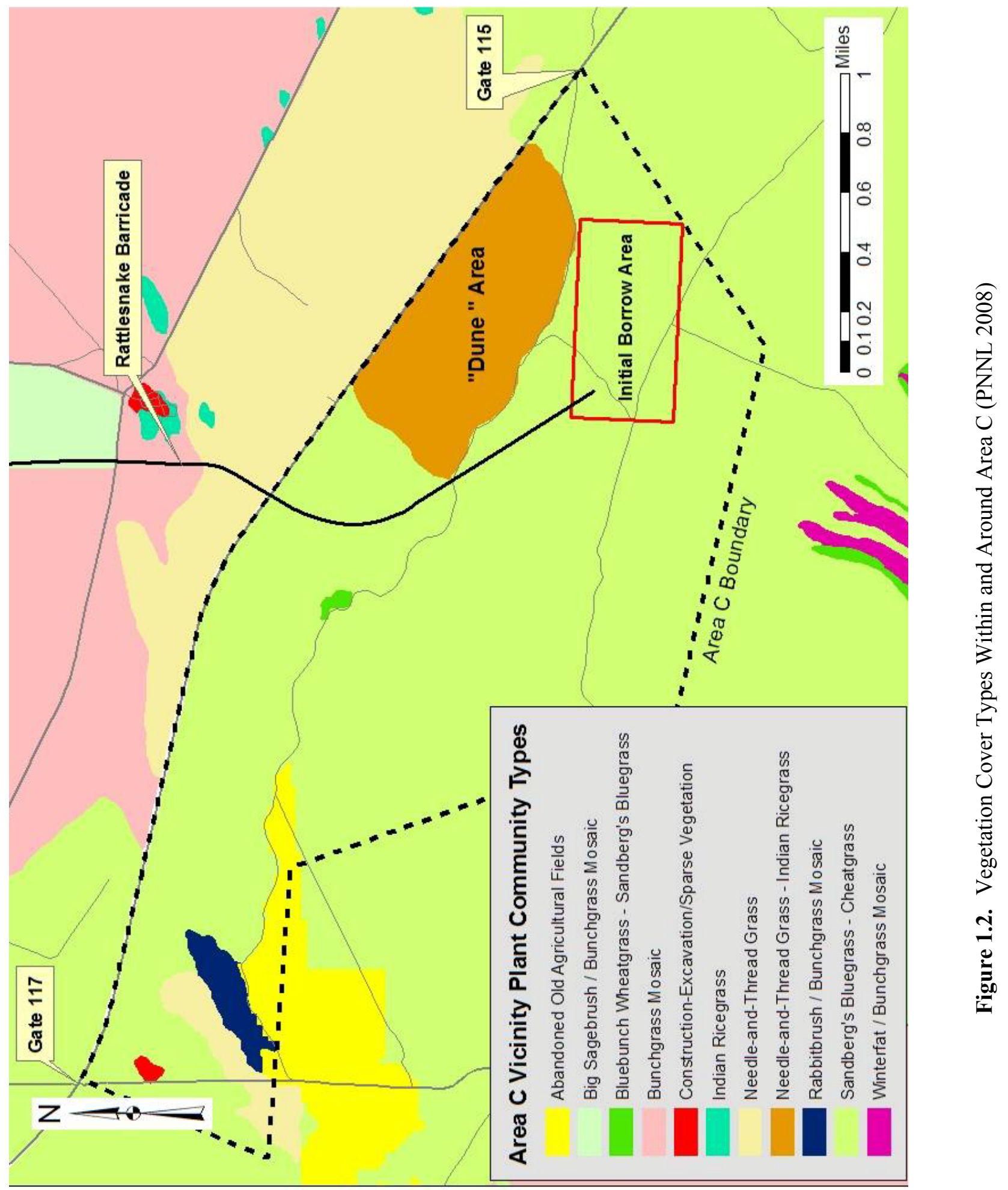




\subsection{Methods}

The sampling strategy applied for this survey is consistent with methods currently used by the Washington Natural Heritage Program (WNHP) within the Department of Natural Resources for evaluating shrub-steppe communities within Washington (Rex Crawford, plant ecologist, WNHP, personal communication, 10 September 2009). Surveys were conducted by experienced shrub-steppe botanists in mid-September after most plant growth was completed for the 2009 growing season. All plants encountered during sampling were identified to species except in two sampling quadrats where insufficient plant material was found to make a reliable identification of a single individual.

The dune portion of the site was surveyed on 14 September 2009. The survey team walked two transects, each approximately 1 mile long, roughly parallel to SR 240, approximately 200 meters apart. Ten sample sites were randomly selected, typically by walking a preselected number of paces (typically 400) and stopping at the last pace. The coordinates of each sampling site were determined with a Global Positioning System unit. Sample-site locations are depicted in Figure 2.1. At each sample site, vegetation canopy cover was estimated in four 0.5 -meter x 1.0-meter quadrats, placed 1 meter from the stop point, in each of four perpendicular directions (Figure 2.2. Within each quadrat, cover was visually estimated for each species to the nearest percentage, and the presence of cryptogamic crust (mosses, lichens, algae) was noted. All species observed within 5 meters of each reference point were also noted.

The proposed initial borrow area was surveyed on 15 September 2009. A total of six sample locations were selected that were representative of the communities within the 145 -acre initial borrow area. One sample was located near each corner of the proposed borrow area boundary; the other two sampling sites were located in the interior of the area to incorporate some of the observable community variation within the boundaries. The plant community of the initial development area is relatively homogenous, and this arrangement of the sampling locations was used to ensure that the full extent of the area was included. The location of each sample is depicted in Figure 2.1. Measurements of vegetation at each sample site followed the procedures described above.

The sampling data were used to calculate the average total canopy cover by species for each of the areas characterized. The relative canopy cover (proportion of the total canopy cover) was also determined for native and alien grasses and forbs.

All field surveys and measurements were conducted by J. L Downs and M. R. Sackschewsky of PNNL; Mr. Lee Hoppis of the Yakama Nation observed and provided assistance each day. 


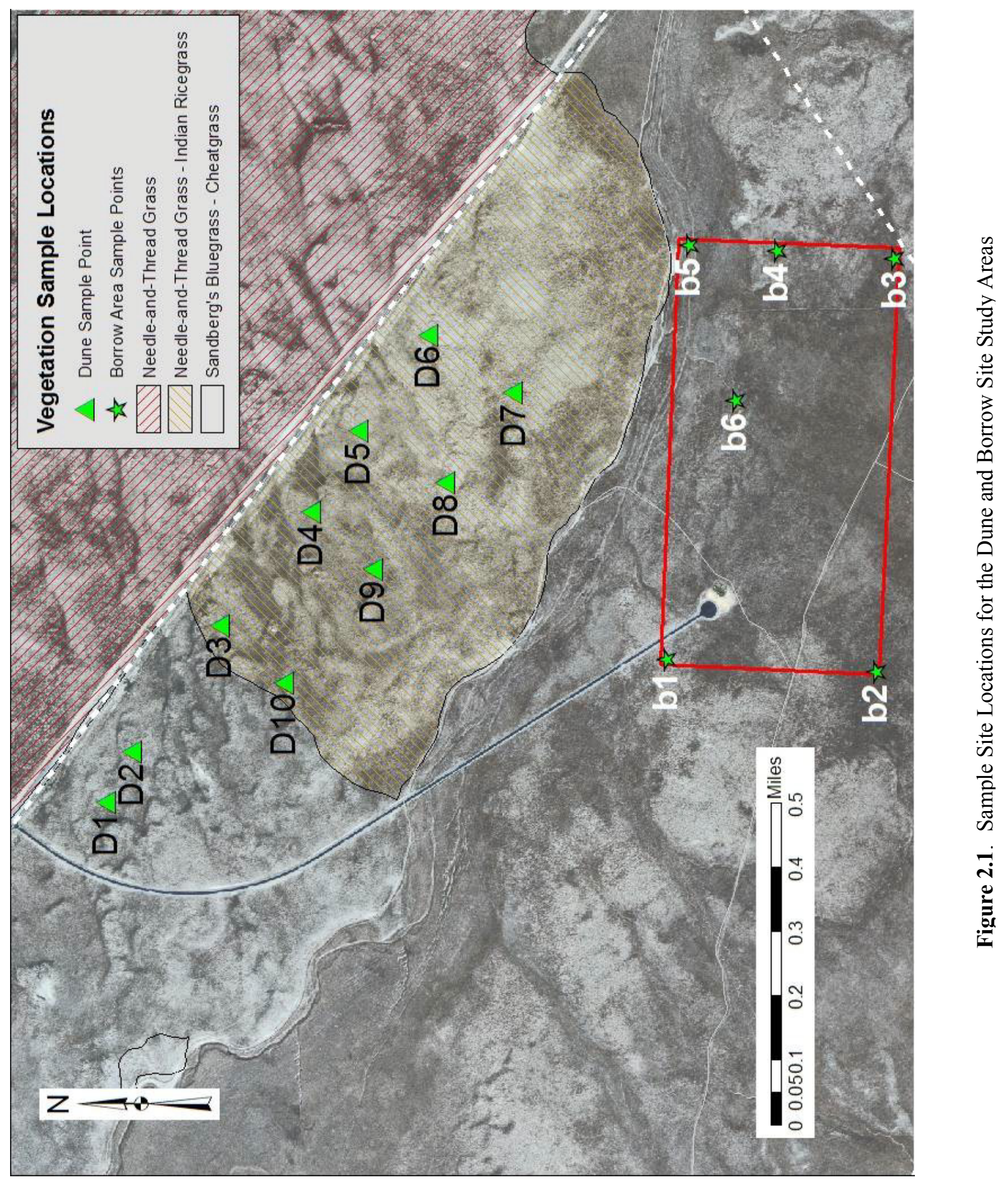




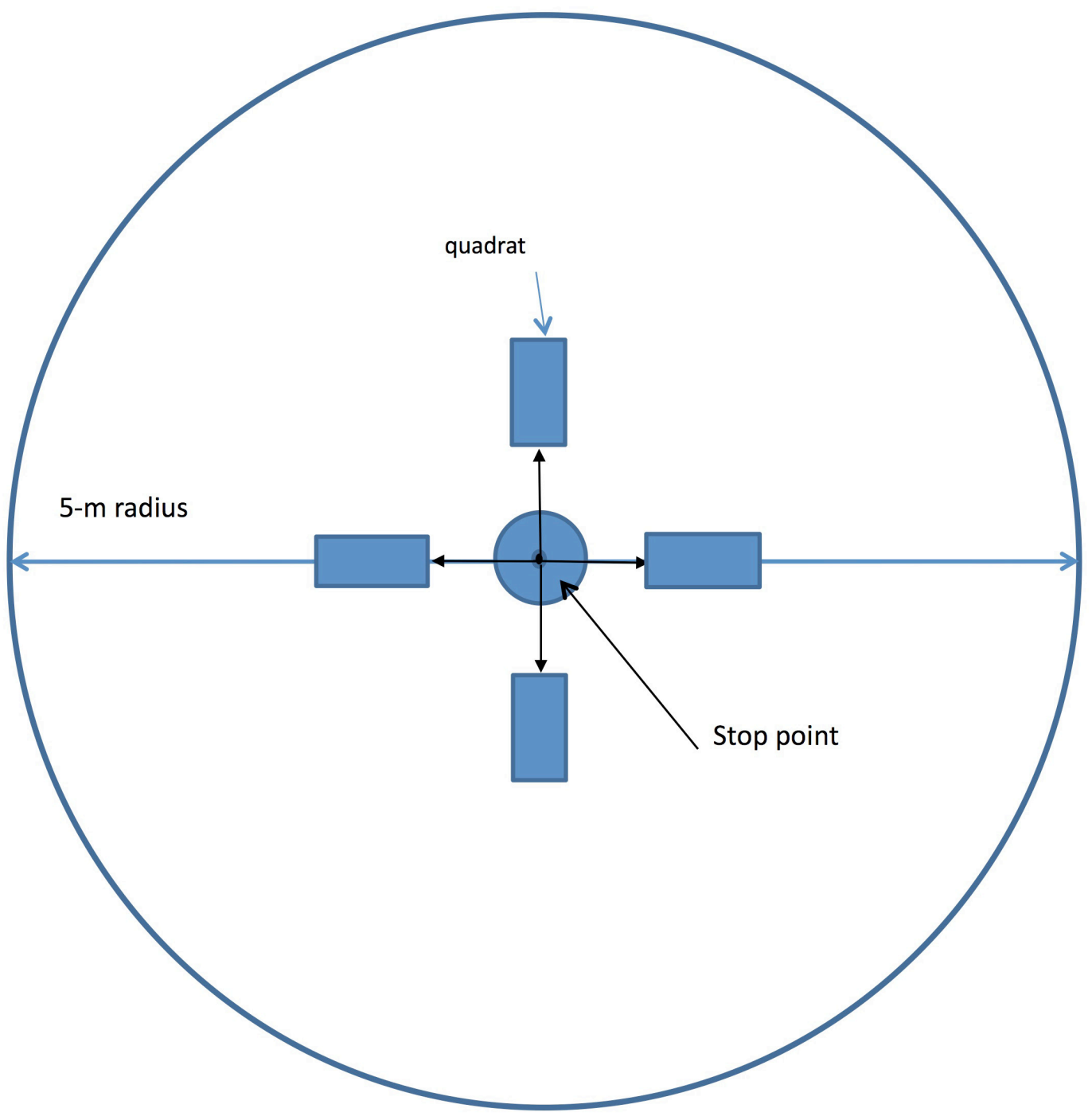

Figure 2.2. Layout of Quadrats and Area Sampled at Each Sampling Site 


\subsection{Results}

The two study areas were found to have very different vegetation cover and composition characteristics. The dune area was found to be native dominated, with higher species diversity and richness, while the borrow area was found to be dominated by non-natives, with lower species diversity and richness.

The dune area vegetation was dominated by native grasses (primarily needle-and-thread grass). Twenty-two species were identified within the sample quadrats, including four species of perennial bunchgrasses, one species of alien annual grass, eight species of native perennial forbs, five species of native annual forbs, and four species of alien annual forbs (Table 3.1). Cryptogamic crust was observed in $65 \%$ of the sample plots. Total canopy cover in the dune community averaged nearly $47 \%$, of which well over half was contributed by perennial grasses. Annual grass (i.e., cheatgrass) cover averaged about $13 \%$ (Table 3.2). Native forbs provided about three times more canopy cover than alien forbs. Needleand-thread grass was present in nearly $88 \%$ of the sample plots, with an average canopy cover of nearly $20 \%$ across the sample quadrates. In comparison, Indian ricegrass was present in about one-eighth of the plots, providing slightly over $1 \%$ of the total average canopy cover. Cheatgrass was present in all but one of the sample plots, providing greater than $25 \%$ cover in only three plots and less than $10 \%$ cover in 19 of the 40 sample plots.

Table 3.1. Species Richness (Number of Species) at the Dune and Borrow Area Sites

\begin{tabular}{lcccccc}
\hline & Total & \multicolumn{3}{c}{ Native Species } & \multicolumn{2}{c}{ Alien Species } \\
\cline { 3 - 7 } Richness, & Perennial & Perennial & Annual & Annual & Annual \\
Area & $n$ & Grass & Forbs & Forbs & Forbs \\
\hline Dune & 22 & 4 & 8 & 5 & 1 & 4 \\
Borrow site & 13 & 1 & 2 & 3 & 2 & 5 \\
\hline
\end{tabular}

Table 3.2. Average Total and Relative Canopy Cover at the Dune and Borrow Sites

\begin{tabular}{lccccc}
\hline \multicolumn{7}{c}{ Average Total Canopy Cover (\%) } \\
\hline \multicolumn{7}{c}{ Area } & Perennial & Annual & Native & Alien & \\
& Grass & Grass & Forb & Forb & Total \\
\hline Dune $(n=40)$ & 26.0 & 13.2 & 5.7 & 1.8 & 46.7 \\
Borrow site $(n=24)$ & 1.7 & 45.3 & 7.1 & 4.5 & 58.6 \\
\hline \multicolumn{7}{c}{ Relative Cover (\%) } & & \\
\hline \multicolumn{7}{c}{ Perennial } & Annual & Native & Alien & \\
& Grass & Grass & Forb & Forb & Total \\
\hline Dune & 55.6 & 28.3 & 12.2 & 3.9 & 100.0 \\
Borrow site & 2.8 & 77.3 & 12.1 & 7.7 & 100.0 \\
\hline
\end{tabular}


The most frequently occurring perennial forbs were pale evening primrose (Oenothera pallida), dune scurf-pea (Psoralidium laneolatum), and turpentine springparsley (Pterixia terebinthina), the latter of which provided more total average cover than any other perennial forb. The most frequent native annual forbs were shy gilia (Gilia sinuata) and matted cryptantha (Cryptantha circumscissa). Tumble mustard (Sisymbrium altissimum) was the most frequent non-native annual forb, providing more total average cover than other members of that group.

The complete set of vegetation cover data for the dune site is provided in Table 3.3. No shrubs occurred in the dune site sample plots; total shrub cover within the dune community was less than $1 \%$, with green rabbitbrush (Chrysothamnus viscidiflorus) the most common shrub. A few big sagebrush shrubs were also observed.

The borrow site vegetation was dominated by alien annual grasses (primarily cheatgrass). Thirteen species were observed, including one perennial bunchgrass, two annual grasses, two species of native perennial forbs, three species of native annual forbs, and five species of alien annual forbs (Table 3.1). Cryptogamic crust was observed in $50 \%$ of the sample plots. Total canopy cover across the borrow site plots averaged nearly 59\%; over three-fourths was provided by exotic annual grass cover (mainly cheatgrass, but some bulbous bluegrass, Poa bulbosa) (Table 3.2). Native perennial bunchgrass cover averaged less than $2 \%$; the only grass observed in this category was Sandberg's bluegrass.

Overall, native forbs provided almost $12 \%$ of the canopy cover at the borrow site. However, this total was due almost entirely to the high canopy cover provided by turpentine springparsley at the first measurement site (B1). Site B1 was the only sample site located in the 2007 Wautoma fire footprint. Turpentine springparsley was also present at sample site B4 (along the eastern edge of the borrow area), but the cover at sample site B1 comprises approximately two-thirds of the total measured cover for native forbs. Where turpentine springparsley occurs, it provides a significant amount of cover, but it occurs in only select microhabitats that are not representative of the borrow area as a whole. Other native forbs comprised less than 1\% canopy cover throughout the borrow area. On average, alien forbs provided $4.6 \%$ canopy cover within the borrow area. Cheatgrass was present in $100 \%$ of the sample plots and provided greater than 50\% canopy cover in nearly half of the plots. Three alien annual forbs - tumble mustard, jagged chickweed (Holosteum umbellatum), and Russian thistle (Salsola tragus) -were the other most frequently occurring species (54\%, 46\%, and 38\% frequency, respectively) and, when combined, provided $4.1 \%$ canopy cover on average across the borrow area sampling plots.

The complete set of vegetation cover data for the borrow site is provided in Table 3.4. A complete list of species observed within the dune and borrow-site study plots is provided in Table 3.5. 


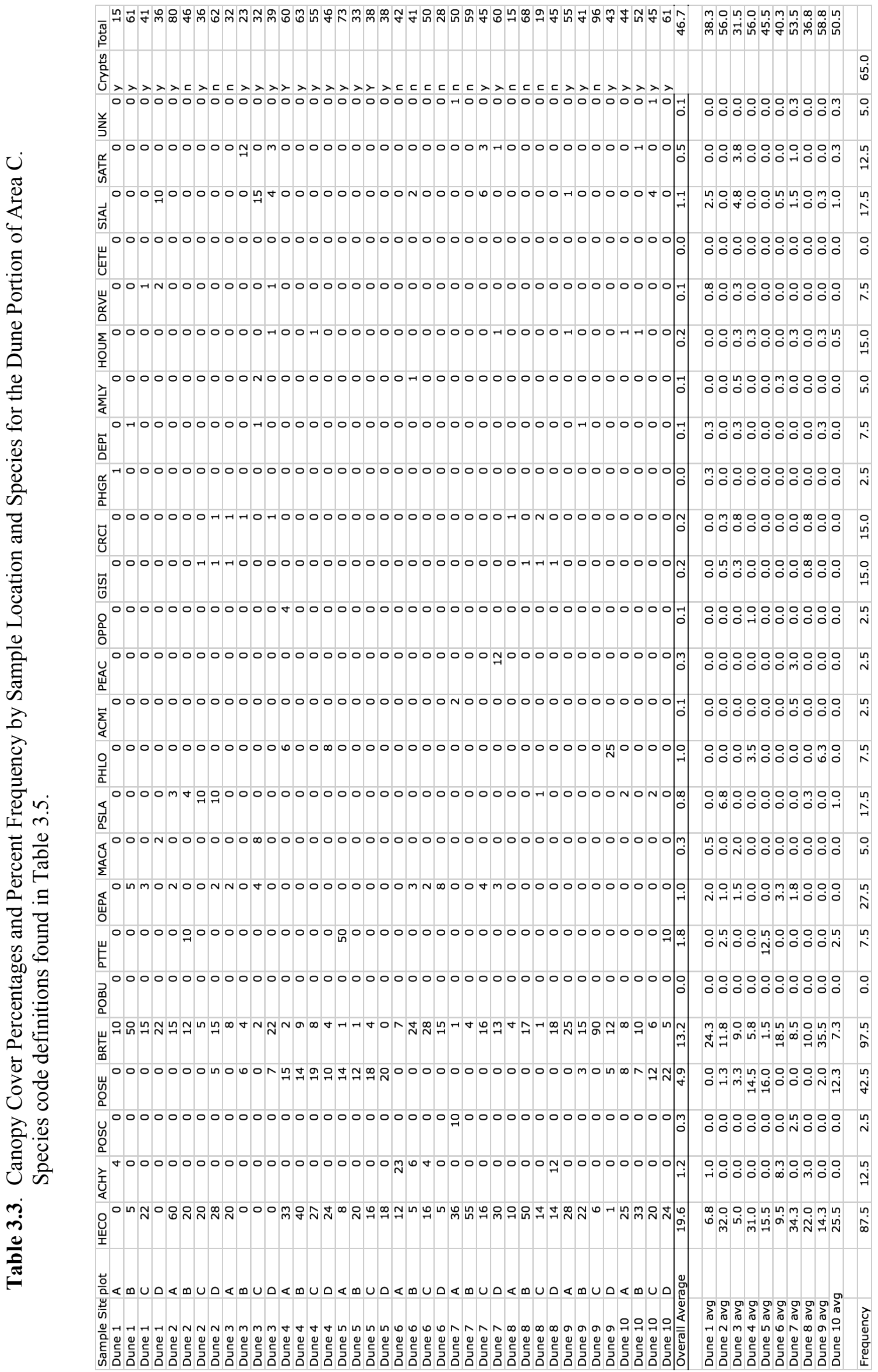




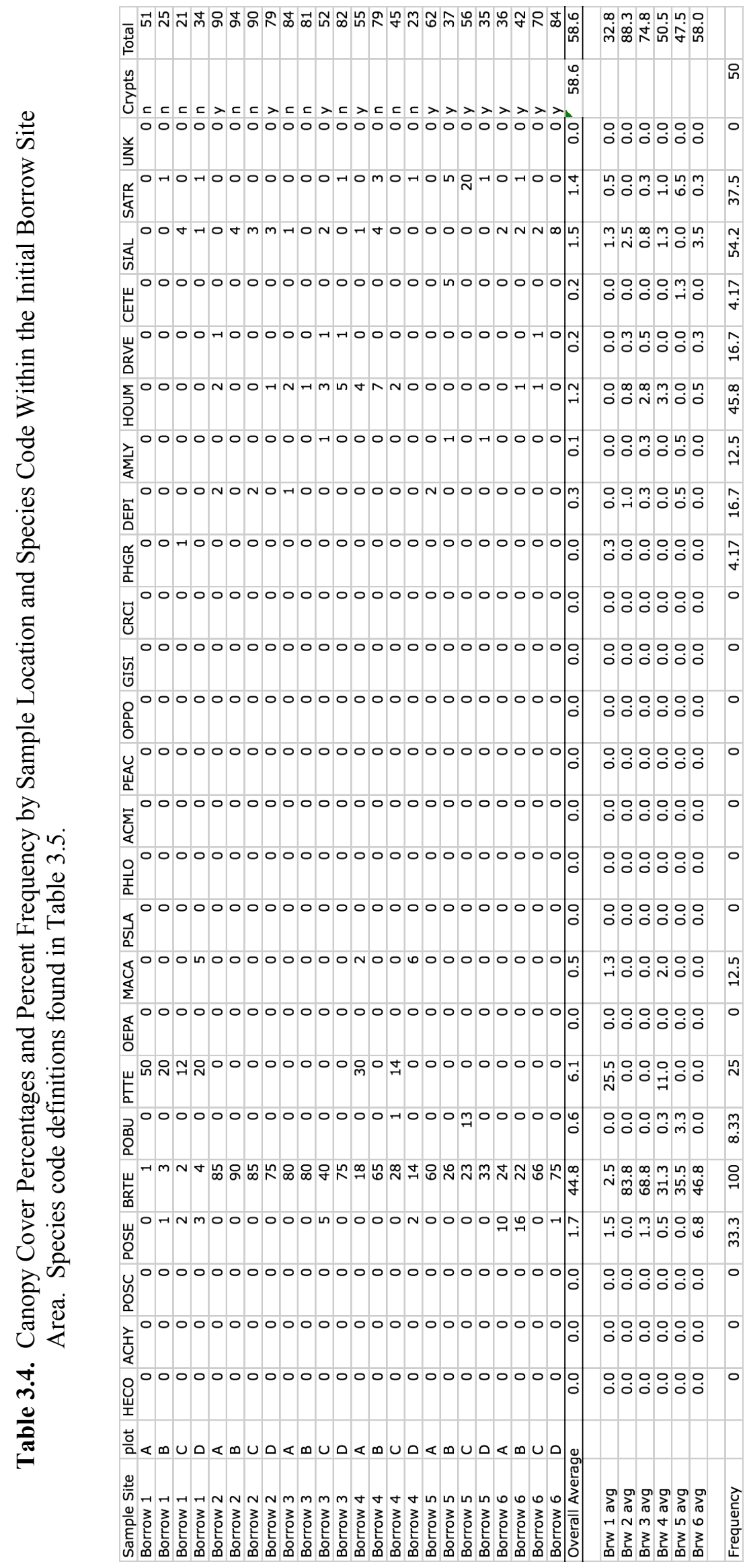


Table 3.5. Species Observed Within Sample Plots at the Dune and Borrow Sites Within Area C

\begin{tabular}{|c|c|c|c|c|}
\hline Code & Scientfic Name & Common Name & Life Form & Native / Alien \\
\hline HECO & Hesperostipa comata (Stipa comata) & needle-and-thread grass & Perennial bunchgrass & Native \\
\hline ACHY & Achnatherum hymenoides (Oryzopsis hymenoides) & indian ricegrass & Perennial bunchgrass & Native \\
\hline POSC & Poa scabrella (a large form of $P$. secunda) & pine bludegrass & Perennial bunchgrass & Native \\
\hline POSE & Poa secunda & Sandberg's bluegrass & Perennial bunchgrass & Native \\
\hline BRTE & Bromus tectorum & cheatgrass & Annual grass & Alien \\
\hline POBU & Poa bulbosa & bulbous bluegrass & Annual grass & Alien \\
\hline PTTE & Pterixia terebinthina (Cymopteris terebinthinus) & turpentine springparsley & Perennial forb & Native \\
\hline OEPA & Oenothera pallida & pale eveningprimrose & Perennial forb & Native \\
\hline MACA & Machaeranthera canescens & hoary aster & Perennial forb & Native \\
\hline PSLA & Psoralidium lanceolatum (Psoralea lanceolata) & dune scurfpea & Perennial forb & Native \\
\hline PHLO & Phlox longifolia & longleaf phlox & Perennial forb & Native \\
\hline ACMI & Achillea millefolium & yarrow & Perennial forb & Native \\
\hline PEAC & Penstemon accuminatus & sand beardtongue & Perennial forb & Native \\
\hline OPPO & Opuntia polycantha & prickly pear & Perennial forb & Native \\
\hline GISI & Gilia sinuata & shy gilia & Annual forb & Native \\
\hline CRCI & Cryptantha circumscissa & matted cryptantha & Annual forb & Native \\
\hline PHGR & Phlox gracilis (Microsteris gracilis) & pink microsteris & Annual forb & Native \\
\hline DEPI & Descurainia pinnata & western tanseymustard & Annual forb & Native \\
\hline HOUM & Holosteum umbellatum & jagged chickweed & Annual forb & Alien \\
\hline DRVE & Draba verna & spring whitlowgrass & Annual forb & Alien \\
\hline CETE & Ceratocephala testiculata (Ranunculus testiculatus) & bur buttercup & Annual forb & Alien \\
\hline AMLY & Amsinckia lycopsoides & fiddleneck & Annual forb & Native \\
\hline SIAL & Sisymbrium altissimum & tumblemustard & Annual forb & Alien \\
\hline SATR & Salsola tragus (Salsola kali) & Russian thistle & Annual forb & Alien \\
\hline UNK & unidentifiable species & & - & - \\
\hline
\end{tabular}




\subsection{Discussion}

Habitat quality was assessed in two areas within Area C - the stabilized dune area adjacent to SR 240, east of the Area $\mathrm{C}$ access road and the proposed 145-acre initial borrow area located in the flats of the Cold Creek Valley. These areas were found to contain significantly different plant communities.

The WNHP monitors the distribution and status of plant community element occurrences throughout the state (WNHP 2009). An element occurrence is considered an important example of a particular type of plant community that possesses some or most of the characteristics that define that community type and has received relatively little human related disturbance. In other words, it resembles a pre-European settlement plant community. Element occurrences are rated on the inherent quality of the plant community, on size of the occurrence, and the landscape setting of the occurrence - that is, whether it is surrounded by disturbed or undisturbed lands. Habitat quality is based on the native species that are present, the relative abundance of those species, the types and abundance of non-native species, and the presence of other factors such as cryptogamic crust on the soil surface. Quality is graded from A to F. ${ }^{1}$ A community with a quality grade of $\mathrm{A}$ is considered an ideal example of the community, but grade $\mathrm{B}$ is probably the best of what remains in Washington State. Usually a grade of $\mathrm{D}$ is the minimum to be considered an element occurrence. A grade of $\mathrm{F}$ indicates that the site has essentially no remaining characteristics of the native system. The size/landscape factors are similarly graded — a large block of habitat surrounded primarily by other (but possibly lower-quality) native habitat areas may receive a size/landscape grade of A, while a small, isolated example may be rated much lower. The quality and landscape grades can then be averaged for an overall grade. For instance, many of the element occurrences on the Hanford Site are of grade C or D quality; however, because they are of large size and surrounded by other native community types, their overall grade may be as high as $\mathrm{B}$, which is generally considered of high priority for conservation and protection. Also, it is accepted that fire is a natural part of the shrub-steppe ecosystem, so a site can be considered a relatively high-quality occurrence of a shrubdominated community (such as sagebrush/needle-and-thread grass) even if the shrub component is missing due to fire. In such a case, the existing cover type (such as needle-and-thread grass/Indian ricegrass) of a site may be maybe different from the element occurrence type.

The dune area was previously categorized as a needle-and-thread grass/Indian ricegrass community and a bitterbrush/Indian ricegrass element occurrence by The Nature Conservancy in the mid-1990s. We found that the community was clearly dominated by needle-and-thread grass; although Indian ricegrass was present, it occurred at a very low frequency and contributed very little to the overall canopy cover. This site is better characterized as a needle-and-thread grass community and likely a big sagebrush/needle-and-thread grass element occurrence, which is how other Nature Conservancy researchers characterized the adjacent community on the north side of SR 240.

We also determined that the area between the Area $\mathrm{C}$ access road and the high-quality needle-andthread community was inaccurately classified as a cheatgrass/Sandberg's bluegrass community. Although this area is of lower habitat quality than the needle-and-thread grass community just described,

\footnotetext{
1 "Specification for assessing ecological condition of sage-steppe communities." 1996 unpublished document on file at the Washington Natural Heritage Program office, Washington State Department of Natural Resources, Olympia, Washington.
} 


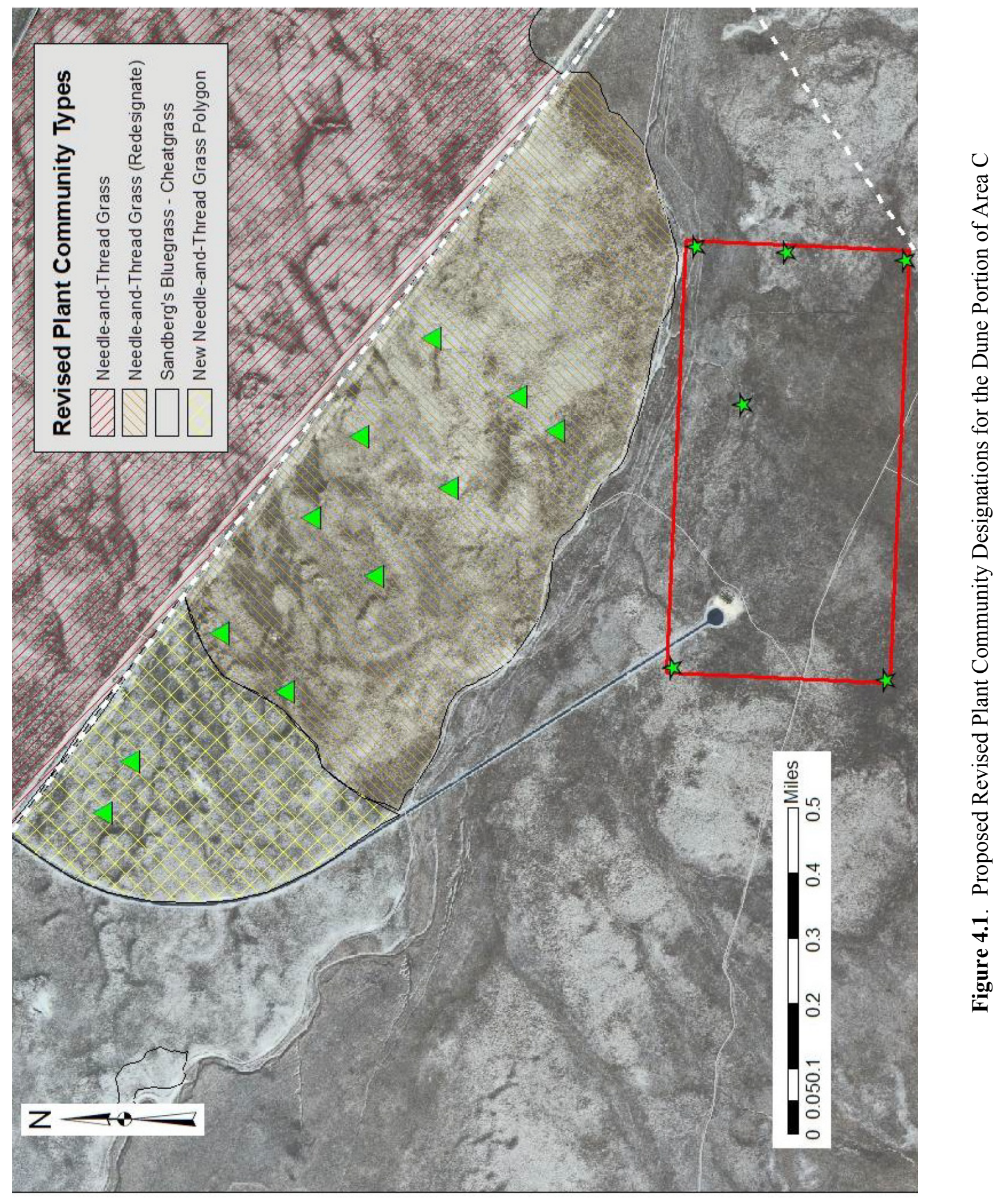


it should also be characterized as a needle-and-thread grass community. This community type (i.e., lower-quality needle-and-thread grass) appeared to continue to the west and north between Cold Creek and SR 240, but that portion of the community was not surveyed. A map depicting the proposed revision to the plant community designations is provided in Figure 4.1. Note that the proposed initial borrow area in Cold Creek Valley is properly classified as cheatgrass/Sandberg's bluegrass.

The 2009 surveys indicate that the dune area contains a relatively high-quality plant community. Needle-and-thread grass cover averaged nearly $20 \%$, with overall perennial grass cover contributing greater than $55 \%$ of the total cover. Alien annual forbs and grasses contributed slightly over $30 \%$ of the total relative cover. Cryptogamic crusts were present at approximately $65 \%$ of the sample plots and were relatively well developed at a number of these plots in spite of the coarse-grained soils typical on this site. These values compare favorably with typical criteria for the definition of high-quality plant community element occurrences, which normally include perennial grasses providing greater than $50 \%$ of the herbaceous cover, alien species less than $20 \%$ cover or less than $30 \%$ relative cover, and a well-developed cryptogamic crust (Crawford 1999). The relative cover of alien annuals is borderline, and the level of crust development may be less than optimal (although less crust is to be expected in these coarse, sandy soils), but the community does appear to be at a minimum in fair and possibly good condition (minimum grade C, possibly B). Figures 4.2, 4.3, and 4.4 depict various locations within this community.

Although the limited data presented here do not clearly indicate it, the area between the access road and the formerly designated dune element occurrence is of lower quality than the rest of the evaluated area. Cheatgrass is much more common in this potion of the site (see Figure 4.5). This area should be considered to be in poor condition and would receive a condition rank of $\mathrm{D}$ at best.

The dune community is essentially attached to a similar and much larger sagebrush/needle-and-thread grass element occurrence on the other side of SR 240 and constitutes the far western edge of the "central Hanford dunes" as described by Hallock et al. (2007). Hallock et al. (2007) assigned a condition rank of $\mathrm{B}$ to the entire central Hanford dune system, with size and landscape factors of A for an overall A rank. Easterly and Salstrom (1998) assigned a condition rank of CD to the sagebrush/needle-and-thread grass community on the other side of SR 240; they provided a size/landscape rank of BA for an overall rank of $\mathrm{C}$.

The proposed initial borrow area located on the flat bottom land of Cold Creek Valley represents shrub-steppe in very poor condition. Examinations of both modern and historic aerial photos do not suggest that this area was farmed, but the site was likely used for grazing and for Army training exercises prior to the designation of the Arid Lands Ecology Reserve. There are essentially no large bunchgrasses present; Sandberg's bluegrass cover is very patchy and comprises less than $2 \%$ of the overall cover. Alien species make up $85 \%$ of the relative cover. This area is not an element occurrence. Figures 4.6, 4.7 , and 4.8 depict various portions of the proposed initial borrow site. 


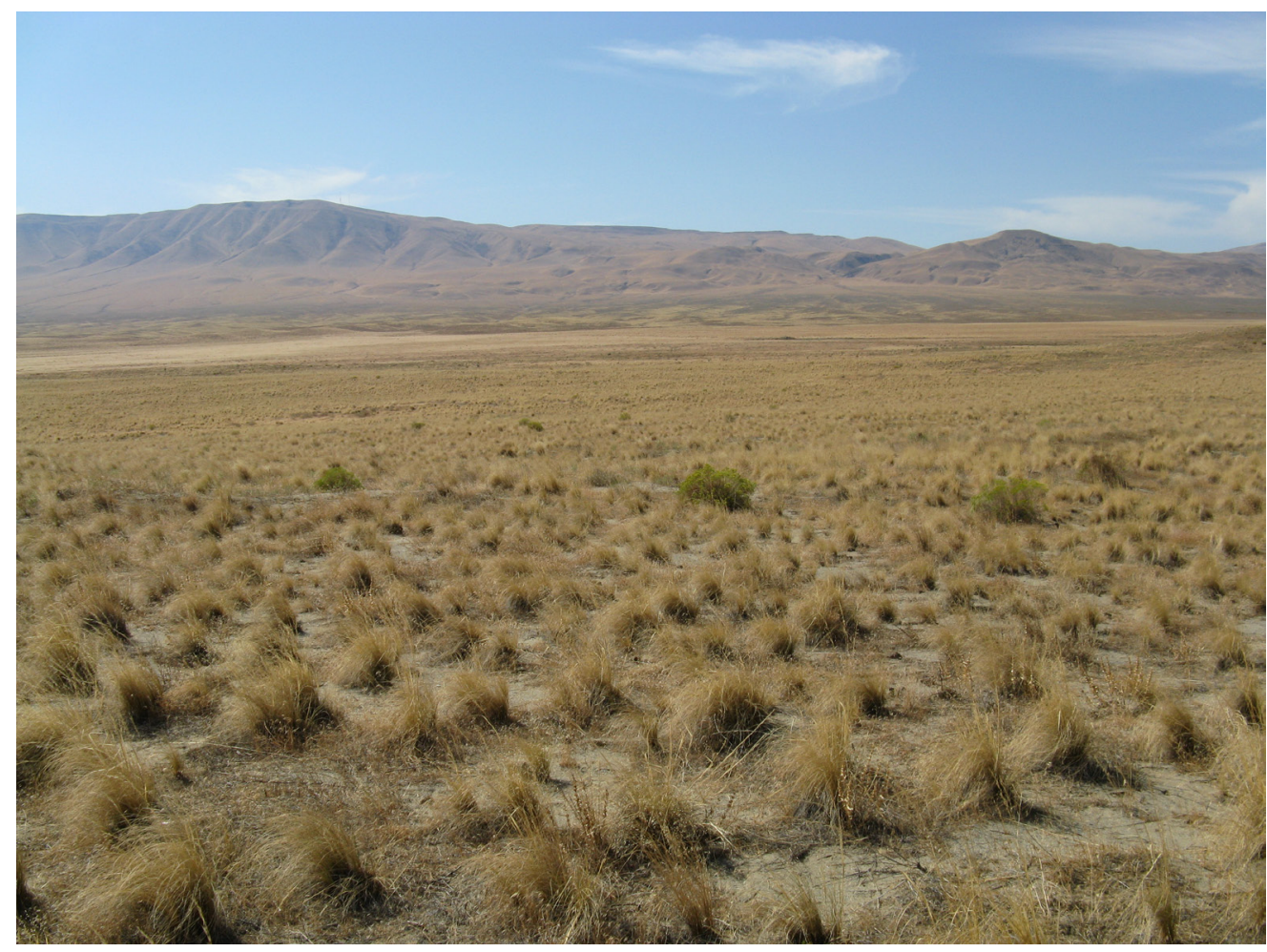

Figure 4.2. Area C Needle-and-Thread Grass Community

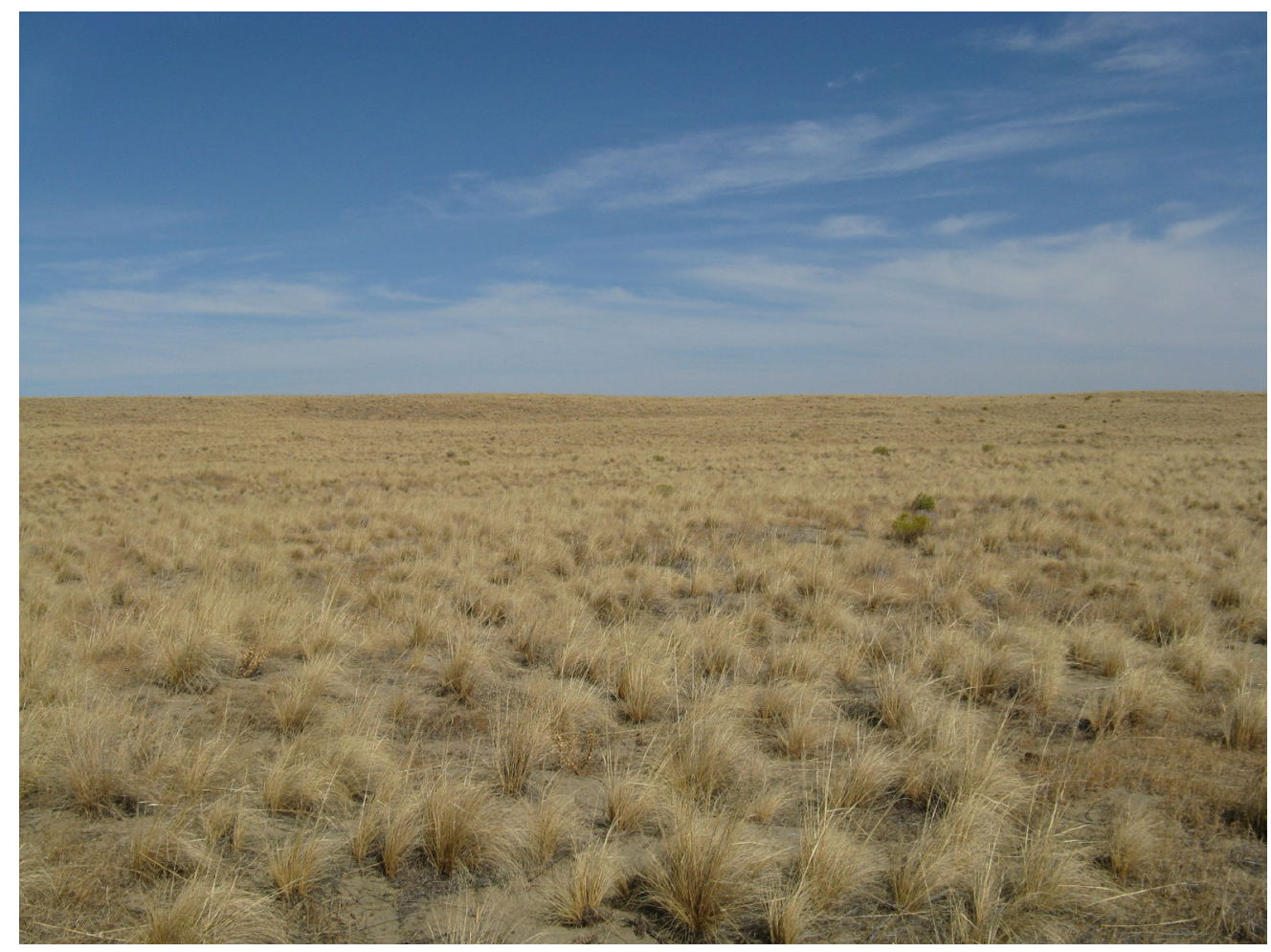

Figure 4.3. Area C Needle-and-Thread Grass Community 


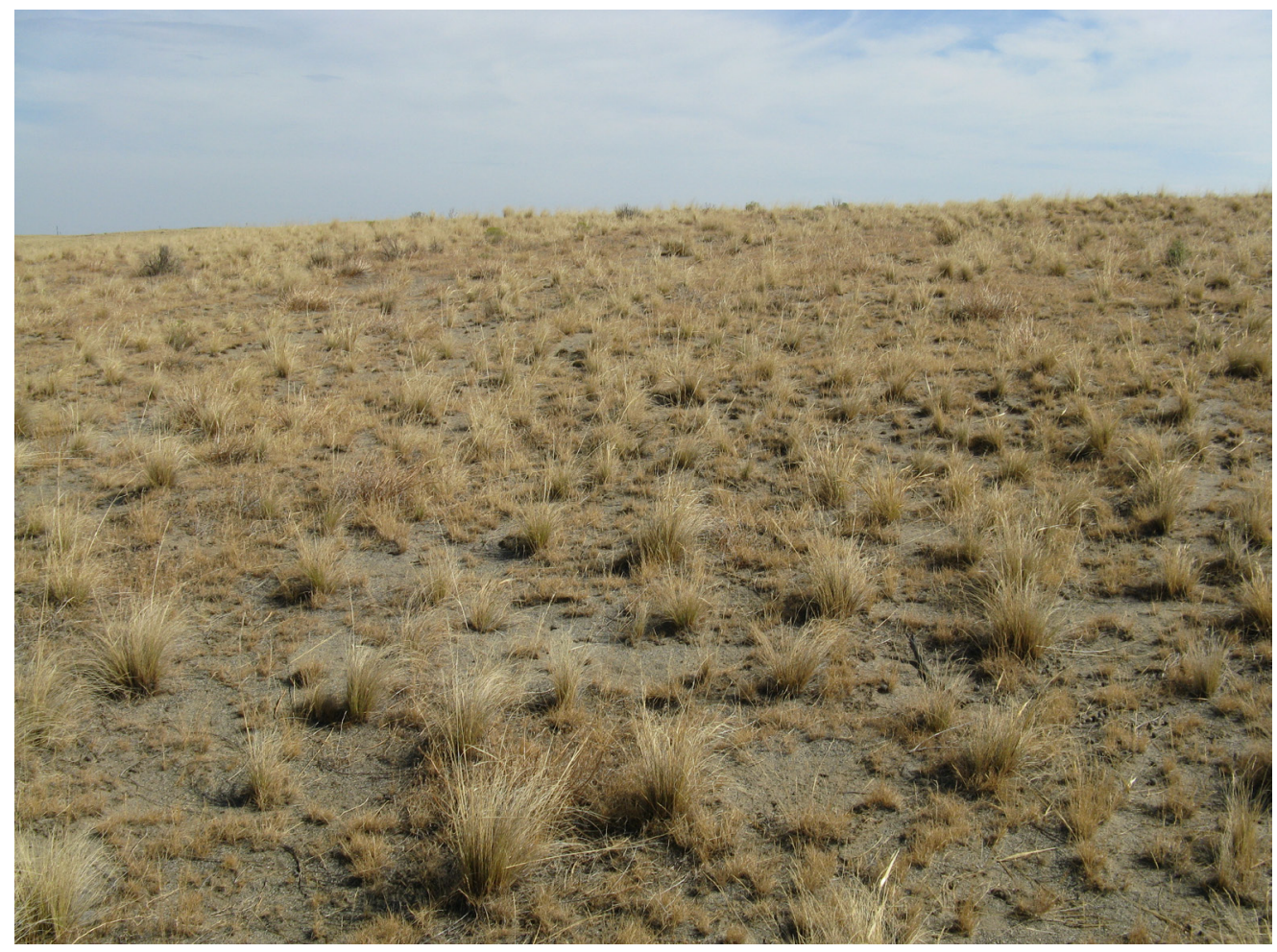

Figure 4.4. Area C Needle-and-Thread Grass Community, Portion with High Sandberg's Bluegrass Cover

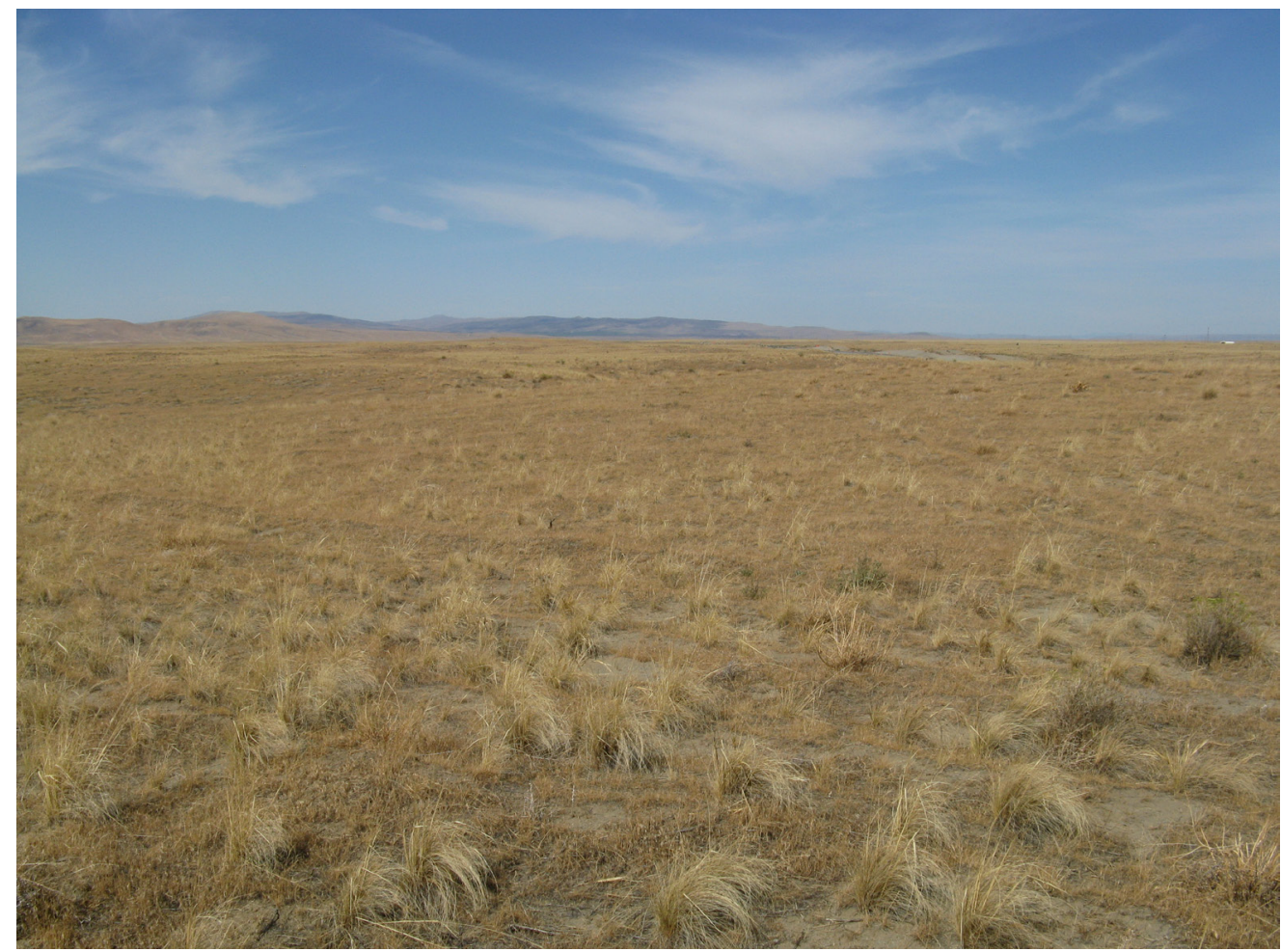

Figure 4.5. Dune Area at Sample Point 3, Looking Northwest Toward Access Road, Showing Greater Cheatgrass Cover, Less Needle-and-Thread Grass Cover 


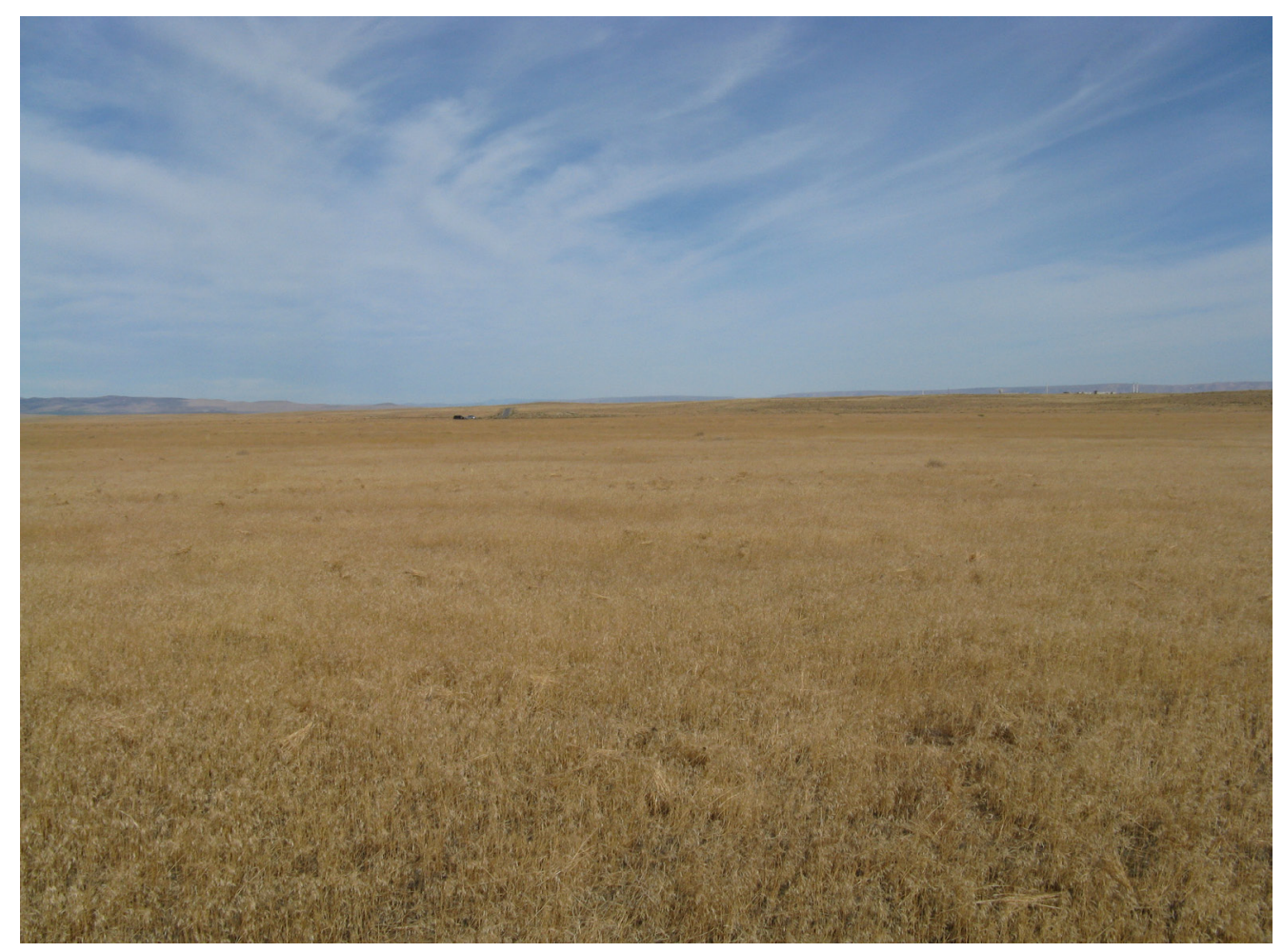

Figure 4.6. Cheatgrass-Dominated Community within Proposed Initial Borrow Area, near Southern Border, Looking Northwest. Note the end of the access road at left-center.

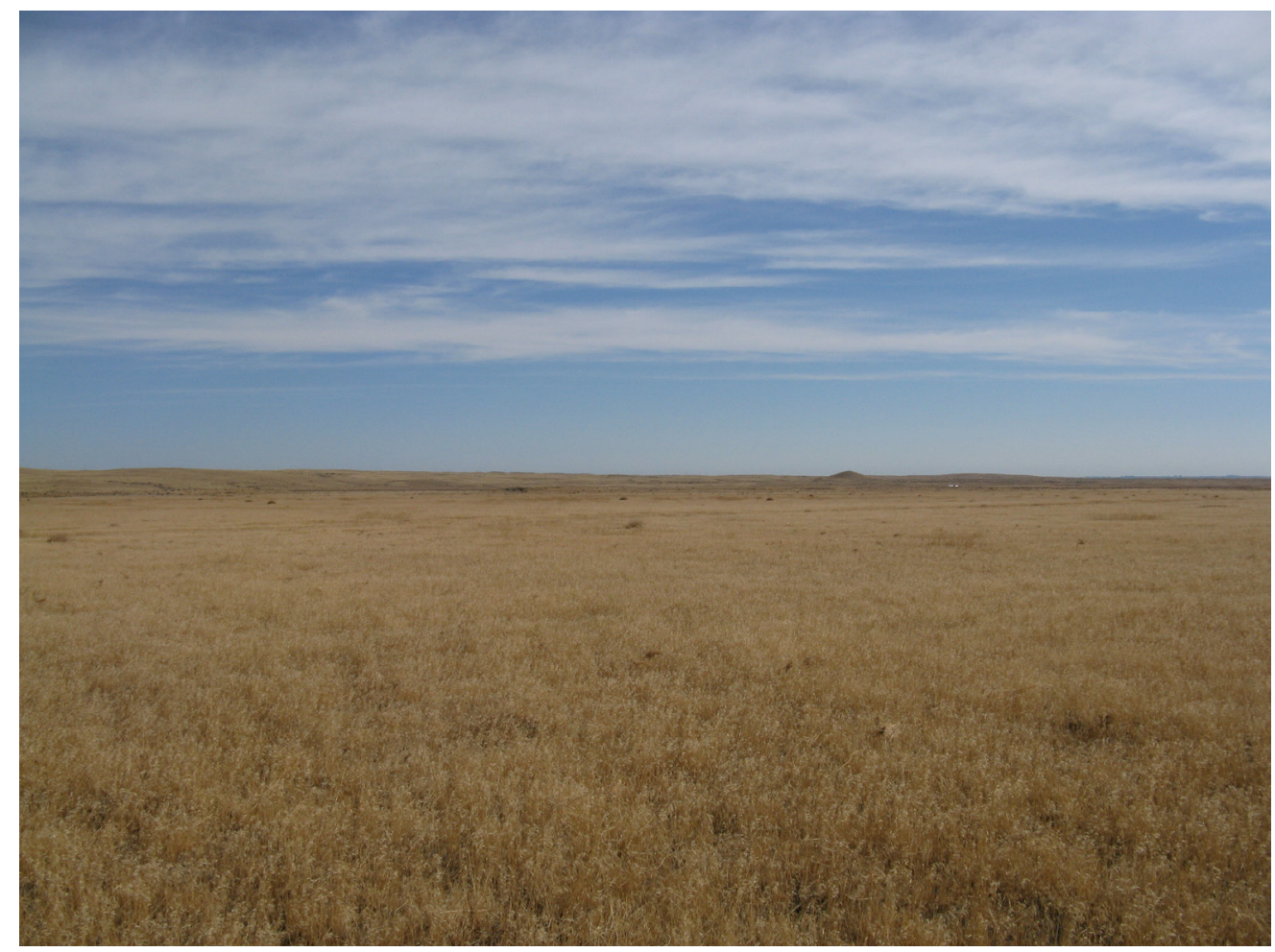

Figure 4.7. Cheatgrass-Dominated Community Within Proposed Initial Borrow Area, near Southern Border, Looking East 


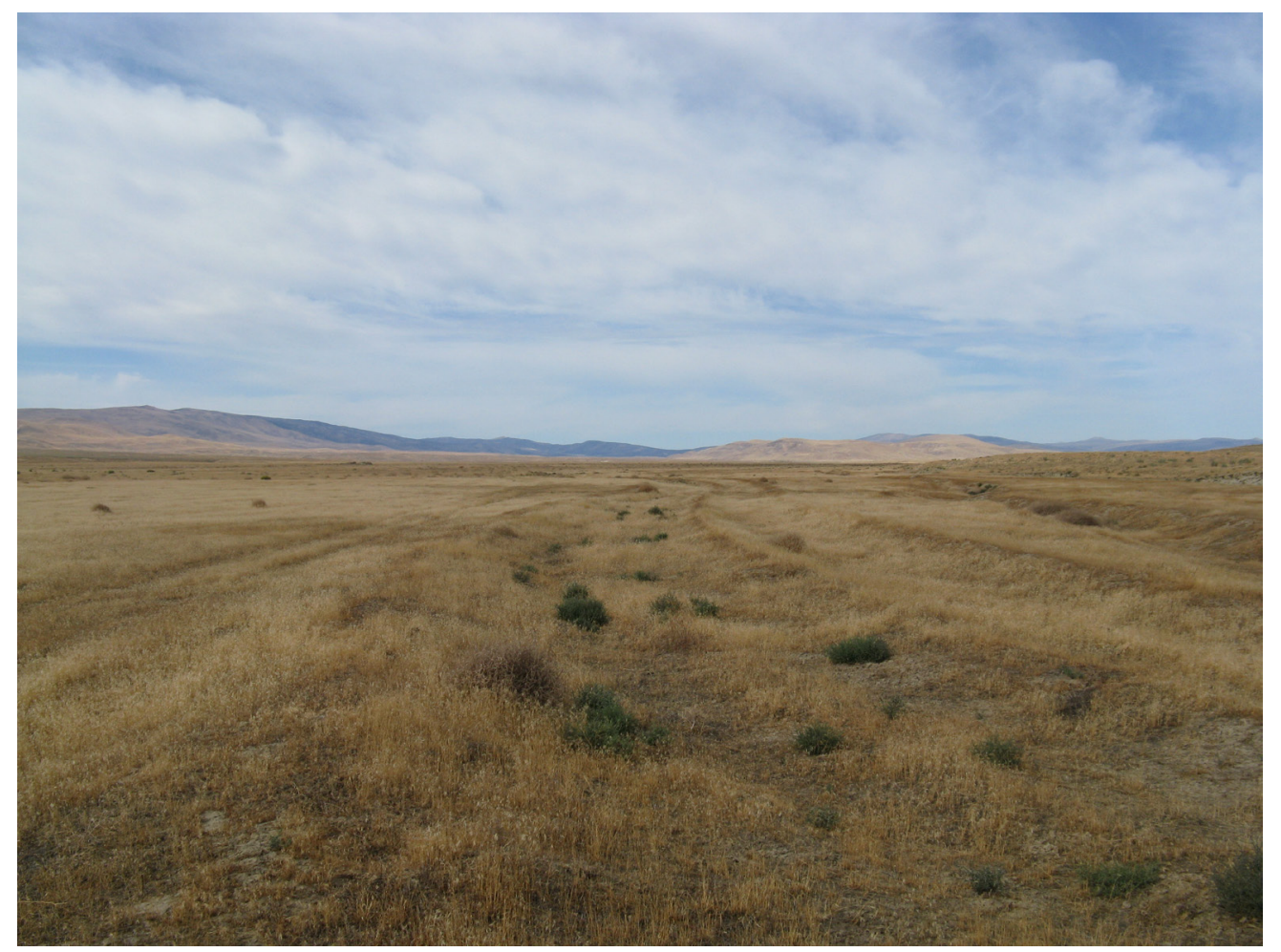

Figure 4.8. Old Road near the Northeastern Corner of the Proposed Initial Borrow Area, Looking West 


\subsection{References}

Crawford R. 1999. 1999 Preliminary Key to Shrub-steppe Plant Communities in Washington State. Report prepared for the Bureau of Land Management, Wenatchee Office. Washington Natural Heritage Program, Washington State Department of Natural Resources, Olympia, Washington.

Easterly R and D Salstrom. 1998. Central Hanford: 1997 Plant Community Inventory. Report to The Nature Conservancy of Washington, Seattle, Washington.

Hallock LA, RD Haugo, and R Crawford. 2007. Conservation Strategy for Washington State Inland Sand Dunes. Natural Heritage Report 2007-05, Washington Natural Heritage Program, Washington State Department of Natural Resources, Olympia, Washington. Available at http://students.washington.edu/ haugor/WANHP_Dunes.pdf(November 2009).

Pabst RJ (ed). 1995. Biodiversity Inventory and Analysis of the Hanford Site: 1994 Annual Report. The Nature Conservancy of Washington, Seattle, Washington.

PNNL (Pacific Northwest National Laboratory). 2008. Hanford Site Vegetation Map. Available at http://www.pnl.gov/ecomon/Veg/vegmap.asp (November 2009).

WNHP (Washington Natural Heritage Program). 2009. Status and Ranking System Used by the Natural Heritage Network. Washington State Department of Natural Resources, Olympia, Washington. Available at http://www1.dnr.wa.gov/nhp/refdesk/lists/stat_rank.html (November 2009). 


\section{Distribution}

No. of

Copies

15 DOE Richland Operations Office

K. D. Leary

A6-38

5 CH2M HILL Plateau Remediation

Company

J. Butner

H8-15
No. of

$\underline{\text { Copies }}$

2 Pacific Northwest National Laboratory

J. L. Downs

K6-85

M. R. Sackschewsky

K6-85

Distr.1 


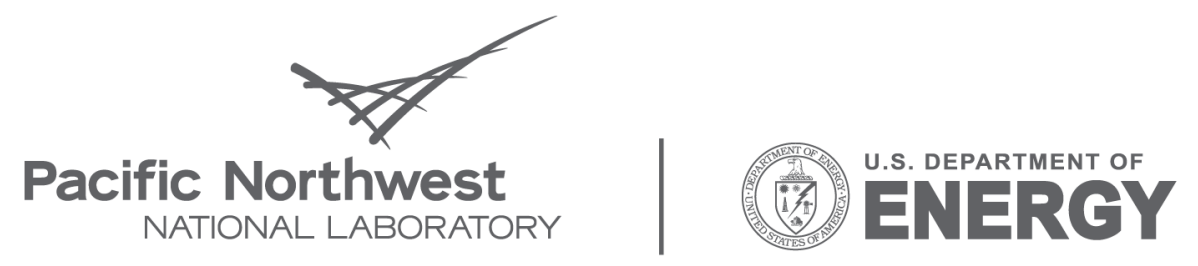

Proudly Operated by Battelle Since 1965

902 Battelle Boulevard

P.O. Box 999

Richland, WA 99352

1-888-375-PNNL (7665)

www.pnl.gov 